\title{
New $C$-terminal hydrazide L-Leucine derivatives as multi-solvent low molecular weight organogelators
}

\author{
Mohamed Mehawed Abdellatif, a* Marie-Christine Averlant-Petit, ${ }^{\mathrm{b}}$ Stefan Loïc, ${ }^{\mathrm{b}}$ \\ Guillaume Pickaert ${ }^{\text {b }}$ \\ ${ }^{a}$ Chemical Industries division, Chemistry of tanning materials and leather technology, \\ National Research Centre, 33 ElBohouth st., BP12622 Dokki-Giza, Egypt, ${ }^{b}$ CNRS, \\ Université de Lorraine, LCPM, UMR 7375, Nancy, F-54001, France.
}

\begin{abstract}
$\mathbf{T}$ HREE new low-molecular-weight gelators (LMWGs) based on L-Leucine derivatives bearing different chain lengths (i.e. 9, 12 or 16) were designed and synthesized. The $N$-terminal carries various alkyl chain lengths while the $C$-terminal is modified with hydrazide moiety. The prepared gelators $\mathbf{1 - 3}$ were fully characterized using ${ }^{1} \mathrm{H},{ }^{13} \mathrm{C}$ NMR, FTIR and mass spectroscopy. The gelation behavior has also been investigated using different organic solvents and oils with determination of critical gelation concentration (CGC). The self-assembly process was investigated by recording FTIR spectra gel states to investigate the driving forces for gelation process. The morphology of the prepared xerogels was studied using SEM.
\end{abstract}

Keywords: Low-Molecular-Weight Gelators, L - Leucine, gelation, self-assembly, hydrogen bonding

\section{Introduction}

In the last decade gels are focusing intense research interest, thanks to the wide application fields in medicine ${ }^{1}$, electronics ${ }^{2}$, catalysis $^{3}$. Among them, organogels are able to immobilize organic solvents such as aliphatics and aromatics. Several strategies can be considered to develop such soft materials. Indeed, in parallel to macromolecular chemical gels, and because of their smart and versatile architecture, supramolecular lowmolecular-weight gelators (LMWGs) have recently gained interest with applications in environmental issues ${ }^{4}$ or drug delivery ${ }^{5}$. LMWGs have the ability to restrict the flow of various fluid phases, thanks to self-assembly process of the predesigned small molecules $(<2000 \mathrm{~g}$. $\mathrm{mol}^{-1}$ ), forming three dimensional fibrillar networks. This assembly is achieved via different intermolecular physical interactions such Hydrogen bonding or van der Waals, hydrophobic interactions. ${ }^{6,7}$ Among the range of bioinspired LMWG, amino acids offers suitably oriented donor and acceptor hydrogen bonding sites promoting self-assembly processes $^{8,9}$.
Moreover, these gelators provide several advantages such as low price, commercial availability, non-toxicity and are eco-friendly. The use of single amino-acid based molecules for the gelation of organic solvents and oils is less exploited and reported than peptides. For instance, Yu et al. have reported -Leucine dihydrazide derivative that could gel many organic solvents. ${ }^{10}$ Zinic et al. have proposed the model of bis(leucine) oxalyl-amide ${ }^{11}$, while Boekhoven et al. have selected the same gelator to study the orthogonal self-assembly and the molecular arrangement in gel fiber. ${ }^{12}$

In this context we have developed a new series of L -leucine derivatives 1-3 (Chart 1) bearing hydrazide moiety and alkyl chain $\left(\mathrm{C}_{9}, \mathrm{C}_{12}\right.$ and $\mathrm{C}_{16}$ ) at $\mathrm{C}$ - and $\mathrm{N}$-terminal positions respectively. The inherent design of this series stands on the $C$-terminal hydrazide modification which was introduced in order to enhance the hydrogen bonding potentials and finally the gelation efficiency. Thus, our gelators are able to trap various organic solvents and several oils.

\footnotetext{
*Corresponding Author: mehawed_666@yahoo.com, guillaume.pickaert@univ-lorraine.fr 


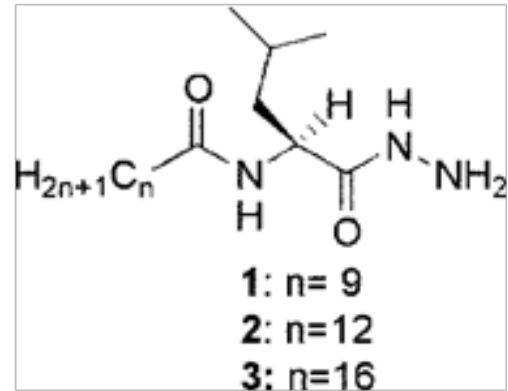

Chart 1. LMWGs 1-3

\section{Experimental}

Materials

L-Leucine methylester hydrochloride, decanoic acid, tridecanoic acid and heptadecanoic acid were purchase from TCI. $N, N, N^{\prime}, N^{\prime}-$ Tetramethyl-O-(1H-benzotriazol-1-yl)uronium hexafluorophosphate (HBTU) was purchased from Iris. $N, N$-Diisopropylethyl amine (DIPEA) , hydrazine monohydrate and all others chemicals and solvents were purchased from Sigma-Aldrich.

\section{Analysis}

All the ${ }^{1} \mathrm{H}$ and ${ }^{13} \mathrm{C}$ NMR spectra were recorded on a Bruker Avance 300 spectrometer. Electrospray mass spectrometry (ESI-MS) was performed with a ToF-Q HR spectrometer. The characteristic absorption peaks for solid and gel samples were studied by ATR-FTIR spectroscopy (ATR Pike Miracle equipped with Germanium crystal, Bruker Tensor 27). All spectra were obtained by 164 scans and $2 \mathrm{~cm}^{-1}$ resolutions in wavenumbers ranging from 4000 to $1000 \mathrm{~cm}^{-1}$. The morphology of the prepared xerogels were analyzed by scanning electron microscopy (SEM, Quanta FEG 250, FEI). The critical gelation concentration (CGC) is determined by visual checking in various fluids (i.e. organic solvents and oils) by test tube inversion. ${ }^{13}$.

Synthesis of $C_{n}-L e u-O M e$ and 1-3
Synthesis of $\mathrm{C}_{n}$-Leu-OMe

A solution of L-Leucine methylester hydrochloride (5 g, $27.50 \mathrm{mmol})$, DIPEA (10.0 $\mathrm{mL}, 2.0 \mathrm{eq}, 55.10 \mathrm{mmol})$ and decanoic acid (5.21 g, 1.1eq, $30.25 \mathrm{mmol})$, tridecanoic acid (6.48 g, $1.1 \mathrm{eq}, 30.25 \mathrm{mmol})$ or heptadecanoic acid (8.18 $\mathrm{g}, 1.1 \mathrm{eq}, 30.25 \mathrm{mmol}$ ) in case of $\mathrm{C}_{9}$-Leu-OMe, $\mathrm{C}_{12}$-Leu-OMe and $\mathrm{C}_{16}$-Leu-OMe, respectively in $(50 \mathrm{~mL})$ chloroform, were added to a solution containing HBTU (11.52 g, 1.1eq, $30.25 \mathrm{mmol})$ and DIPEA (10.0 mL, $2.0 \mathrm{eq}, 55.10 \mathrm{mmol})$ in DMF $(20 \mathrm{~mL})$, and the mixture was stirred at room temperature till completion of the reaction (followed by TLC), Then washed two times consequently with $5 \% \mathrm{HCl}, 10 \% \mathrm{~K}_{2} \mathrm{CO}_{3}$, brine and water. The separated organic phase was dried over anhydrous $\mathrm{MgSO}_{4}$, and the volatiles were removed using a rotary evaporator. The resultant solids were purified collected by precipitation in diethyl ether, then dried in vacuo.

In case of $\mathrm{C}_{9}$-Leu-OMe

${ }^{1} \mathrm{H} \mathrm{NMR}\left(300 \mathrm{MHz}, \mathrm{CDCl}_{3}\right.$ at $\left.25^{\circ} \mathrm{C}\right): \delta(\mathrm{ppm})$ $=6.60(\mathrm{~s}, 1 \mathrm{H}), 4.51(\mathrm{~m}, 1 \mathrm{H}), 3.71(\mathrm{~s}, 3 \mathrm{H}), 2.12(\mathrm{t}$, 2H), 1.54 (br, 6H), 1.19 (br, 14H), 0.85 (br, 9H). ${ }^{13} \mathrm{C} \mathrm{NMR}\left(\mathrm{CDCl}_{3}\right.$ at $\left.25^{\circ} \mathrm{C}\right): \delta(\mathrm{ppm})=174.41,94$, 41, 37.63, 32.86, 30.01, 25.90, 23.05, 15.08, 9.71. Yield $6.5 \mathrm{~g}(80.0 \%)$.

HRMS (ESI): Calcd.for $\mathrm{C}_{17} \mathrm{H}_{33} \mathrm{NO}_{3}[\mathrm{M}+\mathrm{H}]^{+}$: 300.25, Found: 300.25.

In case of $\mathrm{C}_{12}$-Leu-OMe

${ }^{1} \mathrm{H} \mathrm{NMR}\left(300 \mathrm{MHz}, \mathrm{CDCl}_{3}\right.$ at $\left.25^{\circ} \mathrm{C}\right): \delta(\mathrm{ppm})$ $=5.81(\mathrm{~s}, 1 \mathrm{H}), 4.66(\mathrm{~m}, 1 \mathrm{H}), 3.71(\mathrm{~s}, 3 \mathrm{H}), 2.20$ (t, 2H), 1.64 (br, 6H), 1.25 (br, 14H), 0.87-0.94 (br, 9H). ${ }^{13} \mathrm{C} \mathrm{NMR}\left(\mathrm{CDCl}_{3}\right.$ at $\left.25{ }^{\circ} \mathrm{C}\right): \delta(\mathrm{ppm})$ $=174.79,173.55,52.90,50.94,42.74,37.65$, $32.87,30.01,26.27,25.57,23.05,22.67,14.78$. Yield $7.0 \mathrm{~g}(75.0 \%)$.

HRMS (ESI): Calcd.for $\mathrm{C}_{20} \mathrm{H}_{39} \mathrm{NO}_{3}[\mathrm{M}+\mathrm{H}]^{+}$: 341.29, Found: 341.29.

In case of $\mathrm{C}_{16}-\mathrm{Leu}-\mathrm{OMe}$

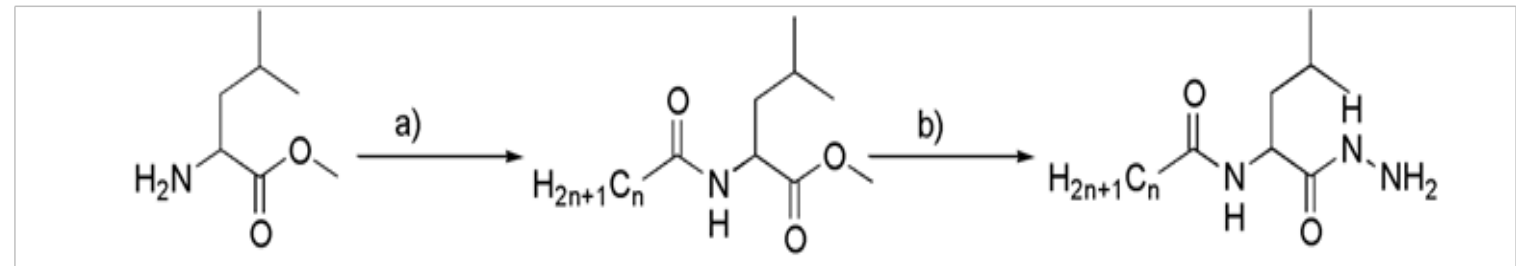

Scheme 1. Reagents and conditions: (a) $\mathrm{C}_{\mathrm{n}} \mathrm{H}_{2 \mathrm{n}+1} \mathrm{COOH}, 1$ equiv, DIEA in DMF/CHCl, $\mathrm{rt}$; (b) $\mathrm{NH}_{2} \mathrm{NH}_{2} \cdot \mathrm{H}_{2} \mathrm{O}, 2$ equiv, $\mathrm{MeOH}, \mathbf{r t}, 18$ h.

J. Text. Color.Polym. Sci. ,15, No. 1 (2018) 
${ }^{1} \mathrm{H} \mathrm{NMR}\left(300 \mathrm{MHz}, \mathrm{CDCl}_{3}\right.$ at $\left.25^{\circ} \mathrm{C}\right): \delta(\mathrm{ppm})=$ $5.92(\mathrm{~s}, 1 \mathrm{H}), 4.63(\mathrm{~m}, 1 \mathrm{H}), 3.71(\mathrm{~s}, 3 \mathrm{H}), 2.18(\mathrm{t}, 2 \mathrm{H})$, $1.60(\mathrm{br}, 6 \mathrm{H}), 1.23$ (br, 14H), 0.92 (br, 9H). ${ }^{13} \mathrm{C}$ NMR $\left(\mathrm{CDCl}_{3}\right.$ at $\left.25^{\circ} \mathrm{C}\right): \delta(\mathrm{ppm})=173.75,172.90,52.58$, $50.49,41.71,36.51,31.89,29.47,25.58,24.86$, $22.77,22.35,21.93,14.06$. Yield $8.9 \mathrm{~g}(82.0 \%)$.

HRMS (ESI): Calcd.for $\mathrm{C}_{24} \mathrm{H}_{47} \mathrm{NO}_{3}[\mathrm{M}+\mathrm{H}]^{+}$: 398.36, Found: 398.36.

\section{Synthesis of 1-3}

To a solution of $\mathrm{C}_{9}$-Leu-OMe, $\mathrm{C}_{12}$-Leu-OMe or $\mathrm{C}_{16}$-Leu-OMe $(5 \mathrm{~g})$ in methanol, hydrazine monohydrate (2 eq.) was added at $0-5^{\circ} \mathrm{C}$ and stirred at room temperature until a precipitate appeared. The white solid was filtered and washed with diethylether. The precipitate was dried in vacuo.

In case of Gelator 1

${ }^{1} \mathrm{H}$ NMR $\left(300 \mathrm{MHz}, \mathrm{CDCl}_{3}\right.$ at $\left.25^{\circ} \mathrm{C}\right): \delta(\mathrm{ppm})$ $=6.60(\mathrm{~s}, 1 \mathrm{H}), 4.51(\mathrm{~m}, 1 \mathrm{H}), 2.12(\mathrm{t}, 2 \mathrm{H}), 1.54(\mathrm{br}$, $6 \mathrm{H}), 1.19$ (br, 14H), 0.85 (br, 9H). ${ }^{13} \mathrm{C}$ NMR $\left(\mathrm{CDCl}_{3}\right.$ at $\left.25^{\circ} \mathrm{C}\right): \delta(\mathrm{ppm})=174.41,94,41,37.63,32.86$, $30.01,25.90,23.05,15.08,9.71$. Yield $4.0 \mathrm{~g}(80.0 \%)$.

HRMS (ESI): Calcd.for $\mathrm{C}_{16} \mathrm{H}_{33} \mathrm{~N}_{3} \mathrm{O}_{2}[\mathrm{M}+\mathrm{Na}]^{+}$: 322.24, Found: 322.23.

In case of Gelator 2

${ }^{1} \mathrm{H}$ NMR $\left(300 \mathrm{MHz}, \mathrm{CDCl}_{3}\right.$ at $\left.25^{\circ} \mathrm{C}\right): \delta(\mathrm{ppm})$ $=5.81(\mathrm{~s}, 1 \mathrm{H}), 4.66(\mathrm{~m}, 1 \mathrm{H}), 2.20(\mathrm{t}, 2 \mathrm{H}), 1.64$ (br, 6H), 1.25 (br, 14H), 0.87-0.94 (br, 9H). ${ }^{13} \mathrm{C}$ NMR $\left(\mathrm{CDCl}_{3}\right.$ at $\left.25^{\circ} \mathrm{C}\right): \delta(\mathrm{ppm})=174.79,173.55$, $52.90,50.94,42.74,37.65,32.87,30.01,26.27$, $25.57,23.05,22.67,14.78$. Yield $3.5 \mathrm{~g}(70.0 \%)$.

HRMS (ESI): Calcd.for $\mathrm{C}_{27} \mathrm{H}_{38} \mathrm{~N}_{2} \mathrm{O}_{3}[\mathrm{M}+\mathrm{Na}]^{+}$:
364.30, Found: 364.29 .

In case of Gelator 3

${ }^{1} \mathrm{H} \mathrm{NMR}\left(300 \mathrm{MHz}, \mathrm{CDCl}_{3}\right.$ at $\left.25^{\circ} \mathrm{C}\right): \delta(\mathrm{ppm})=$ $5.92(\mathrm{~s}, 1 \mathrm{H}), 4.63(\mathrm{~m}, 1 \mathrm{H}), 3.71(\mathrm{~s}, 3 \mathrm{H}), 2.18(\mathrm{t}, 2 \mathrm{H})$, $1.60(\mathrm{br}, 6 \mathrm{H}), 1.23$ (br, 14H), $0.92(\mathrm{br}, 9 \mathrm{H}) .{ }^{13} \mathrm{C}$ NMR $\left(\mathrm{CDCl}_{3}\right.$ at $\left.25^{\circ} \mathrm{C}\right): \delta(\mathrm{ppm})=173.75,172.90,52.58$, $50.49,41.71,36.51,31.89,29.47,25.58,24.86$, $22.77,22.35,21.93,14.06$. Yield $3.25 \mathrm{~g}(65.0 \%)$.

HRMS (ESI): Calcd.for $\mathrm{C}_{23} \mathrm{H}_{48} \mathrm{~N}_{3} \mathrm{O}_{2}[\mathrm{M}+\mathrm{Na}]^{+}$: 420.36, Found: 420.37.

\section{Results and discussion}

Organogelation properties

The ability of the three synthesized compounds 1-3 to form gels with various organic solvents and oils (i.e. alkanes, aromatics, ester, chlorinated and alcohol) and oils (paraffin, olive and sunflower) were evaluated, as shown in Table 1.

As a general overview, organogels were obtained with alkanes (except for gelator $\mathbf{2}$ in $i$-Octane), aromatics and oils. In contrast, our compounds are not efficient for other organic solvent such as dichloromethane, chloroform, methanol and ethyl acetate. For all gelators, the lower CGC were obtained with alkanes. Another general trend concerns the decrease of CGC when gelator alkyl chain lengths increase. For instance, in $n$-Octane, CGC decrease of a factor of 1.5 from $\mathrm{C}_{9}$ to $\mathrm{C}_{12}$ and 1.7 from $\mathrm{C}_{12}$ to $\mathrm{C}_{16}$. In other words, a longer alkyl chain introduces more hydrophobic interactions and thus increase the gelation number (GN) as shown in Figure 1.

TABLE 1. Selected results of the gelation ability screening for 1-3 in various solvents.

G(x): gel / CGC in wt\% / CGC in mM;

OG: opaque gel, TG: transparent gel, PG: partial gel, S: soluble, P: precipitate.

\begin{tabular}{llll}
\hline Solvents & $\mathbf{1}$ & $\mathbf{2}$ & $\mathbf{3}$ \\
\hline Paraffin oil & $\mathrm{TG} / 1.00 / 30.06$ & $\mathrm{TG} / 0.44 / 11.61$ & $\mathrm{TG} / 0.10 / 22.70$ \\
Olive oil & $\mathrm{TG} / 1.50 / 46.35$ & $\mathrm{TG} / 1.00 / 26.82$ & $\mathrm{TG} / 0.45 / 10.38$ \\
Sunflower oil & $\mathrm{TG} / 1.60 / 49.01$ & $\mathrm{TG} / 1.20 / 32.10$ & $\mathrm{TG} / 0.56 / 12.86$ \\
i-Octane & $\mathrm{TG} / 0.90 / 20.76$ & $\mathrm{PG} / \mathrm{N} . \mathrm{A} . / \mathrm{N} . \mathrm{A}$. & $\mathrm{OG} / 0.50 / 8.72$ \\
n-Octane & $\mathrm{OG} / 0.80 / 18.78$ & $\mathrm{OG} / 0.60 / 12.40$ & $\mathrm{OG} / 0.41 / 7.28$ \\
Cyclohexane & $\mathrm{OG} / 0.61 / 15.96)$ & $\mathrm{OG} / 0.52 / 11.88$ & $\mathrm{OG} / 0.31 / 6.08$ \\
Toluene & $\mathrm{TG} / 1.40 / 40.78$ & $\mathrm{TG} / 0.72 / 18.40$ & $\mathrm{TG} / 0.62 / 13.54$ \\
Benzene & $\mathrm{TG} / 1.80 / 53.19$ & $\mathrm{TG} / 0.92 / 23.75$ & $\mathrm{TG} / 0.56 / 12.31$ \\
P-Xylene & $\mathrm{TG} / 1.20 / 34.64$ & $\mathrm{TG} / 0.80 / 20.17$ & $\mathrm{TG} / 0.68 / 14.73$ \\
1,2-Dichlorobenzene & $\mathrm{TG} / 1.20 / 52.30$ & $\mathrm{TG} / 0.73 / 27.99$ & $\mathrm{TG} / 0.53 / 17.30$ \\
Dichloromethane & $\mathrm{S}$ & $\mathrm{S}$ & $\mathrm{S}$ \\
Chloroform & $\mathrm{S}$ & $\mathrm{S}$ & $\mathrm{S}$ \\
Methanol & $\mathrm{S}$ & $\mathrm{S}$ & $\mathrm{S}$ \\
Ethyl Acetate & $\mathrm{S}$ & $\mathrm{PG} / \mathrm{N} . \mathrm{A} . / \mathrm{N} . \mathrm{A}$. & $\mathrm{P}$ \\
\hline
\end{tabular}




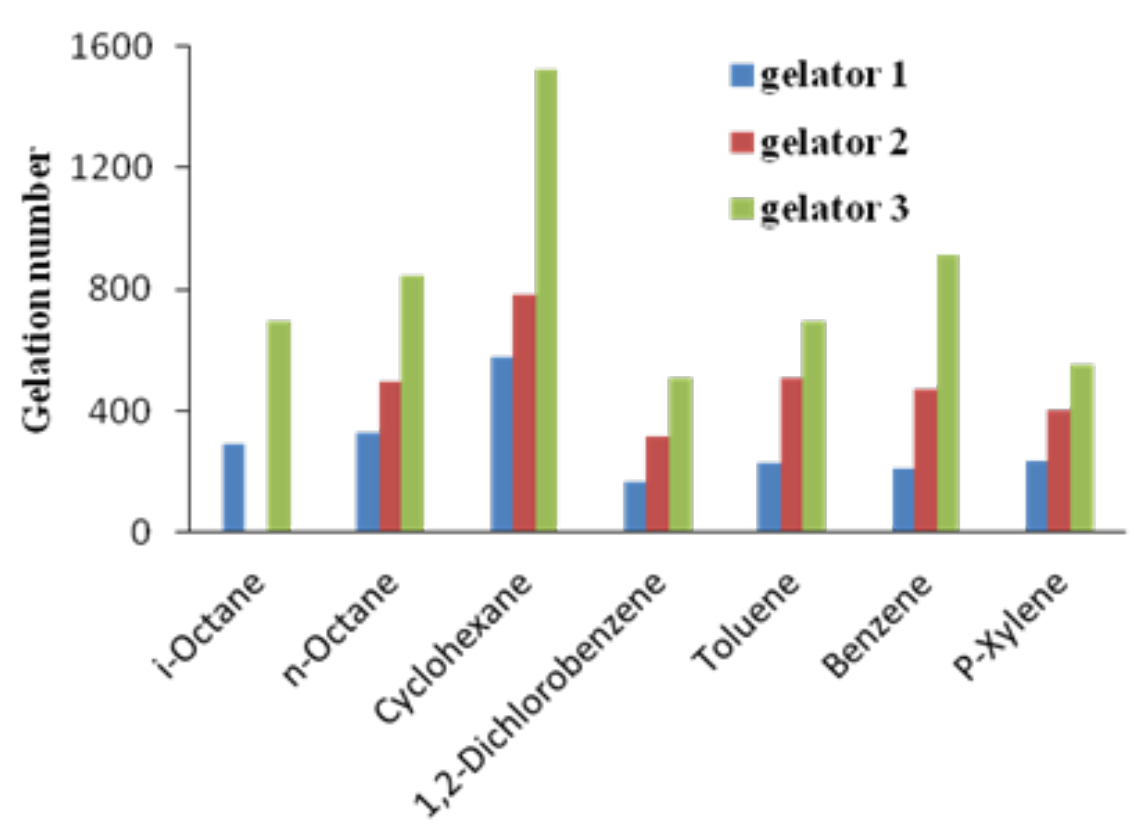

Fig. 1. Gelation number (GN: number of immobilized solvent molecules per gelator molecule) for compounds 1-3 in alkane and aromatic solvents, the GN increase with the length of alkyl chains.

Gelation in aromatic solvents and oils forms transparent gels, when opaque gels are observed in alkanes. Opacity is a consequence of the size of objects found in the gel network. When objects are smaller than light wavelength, gels are transparent. In contrast, gels are more opaque with larger objects. ${ }^{14}$

Methyl ester precursors were also evaluated in order to demonstrate the relevance of the hydrazide moiety. Interestingly, no gels were obtained. This indicates that the presence of hydrazide function is essential for additional hydrogen bonding, which is of primary importance for 1D-self assembly process, subsequently leading to the formation of three dimensional fibrillar networks.

\section{Fourier-transform infrared investigation}

FTIR spectroscopy have been used to investigate, at molecular level, the weak interactions promoting the self-assembly processes. The area of the stretching vibrations of carbonyls (amide and hydrazide) was studied. Spectra of n-octane (Figure 2) and toluene (Figure 3 ) organogels were recorded for all three gelators at $20 \mathrm{mM}$. In the case of n-Octane, study of amide I region shows that gelators 2 and 3 have an extremely similar signature with two major vibrators at 1635 and $1608 \mathrm{~cm}^{-1}$ corresponding to hydrazide and amide $\mathrm{C}=\mathrm{O}$ respectively.
Interestingly, shortening of alkyl chain length provokes slight changes in the self-assembly process at molecular level. Indeed, spectrum of 1 (Figure 2) show the hydrazide carbonyl at 1639 $\mathrm{cm}^{-1}$ and the amide one at $1618 \mathrm{~cm}^{-1}$, instead of 1635 and $1608 \mathrm{~cm}-1$ in the case of gelators 2 and 3. Moreover, weak bands, attributed to free hydrazide and amide carbonyls (obtained from DMSO solutions), found at 1680 and $1661 \mathrm{~cm}^{-1}$ indicates that a small part of gelator molecules is not completely involved in the 3D gel network. Same phenomenon is observed in toluene gels (Figure 3). The spectrum of gelator 1 is different than spectra of 2 and 3.

Morphological study of the prepared xerogels.

SEM was used to investigate the morphology of the obtained materials. The analyzed xerogels were obtained by open air drying the corresponding organogels. The self-assembled nanofibers are entangled leading to formation of three-dimensional network during gel formation as shown in Figure 4. The difference in fibre size are clearly observed, which indicates that the nanofibers are different from a solvent to another.

Further investigations regarding rheological properties and FTIR will be conducted to go further in the understanding of the gelation process. 


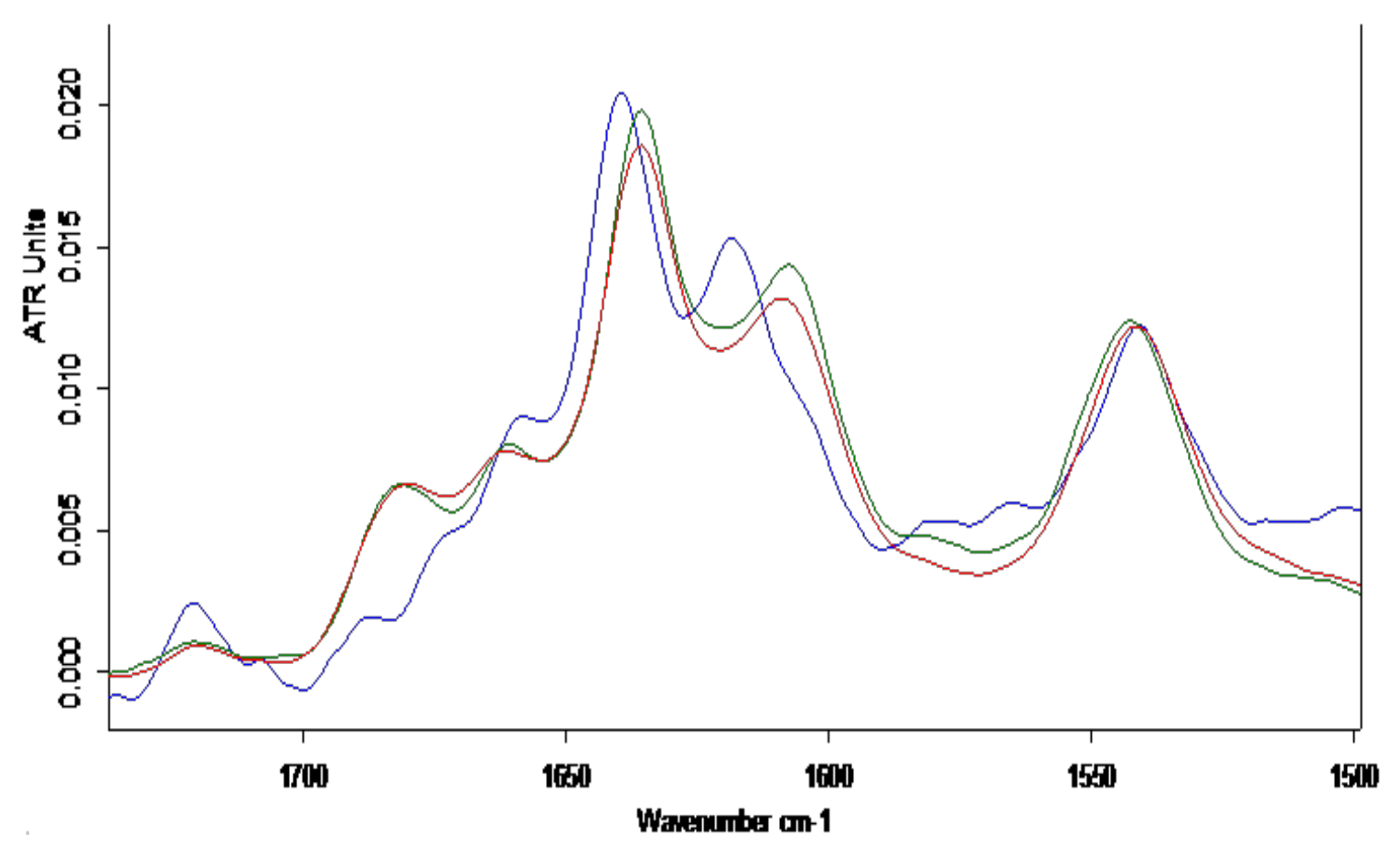

Fig. 2. Amide I region FT-IR spectra of 1 (blue), 2 (red) and 3 (green) in gel state (n-Octane, 20 mM).

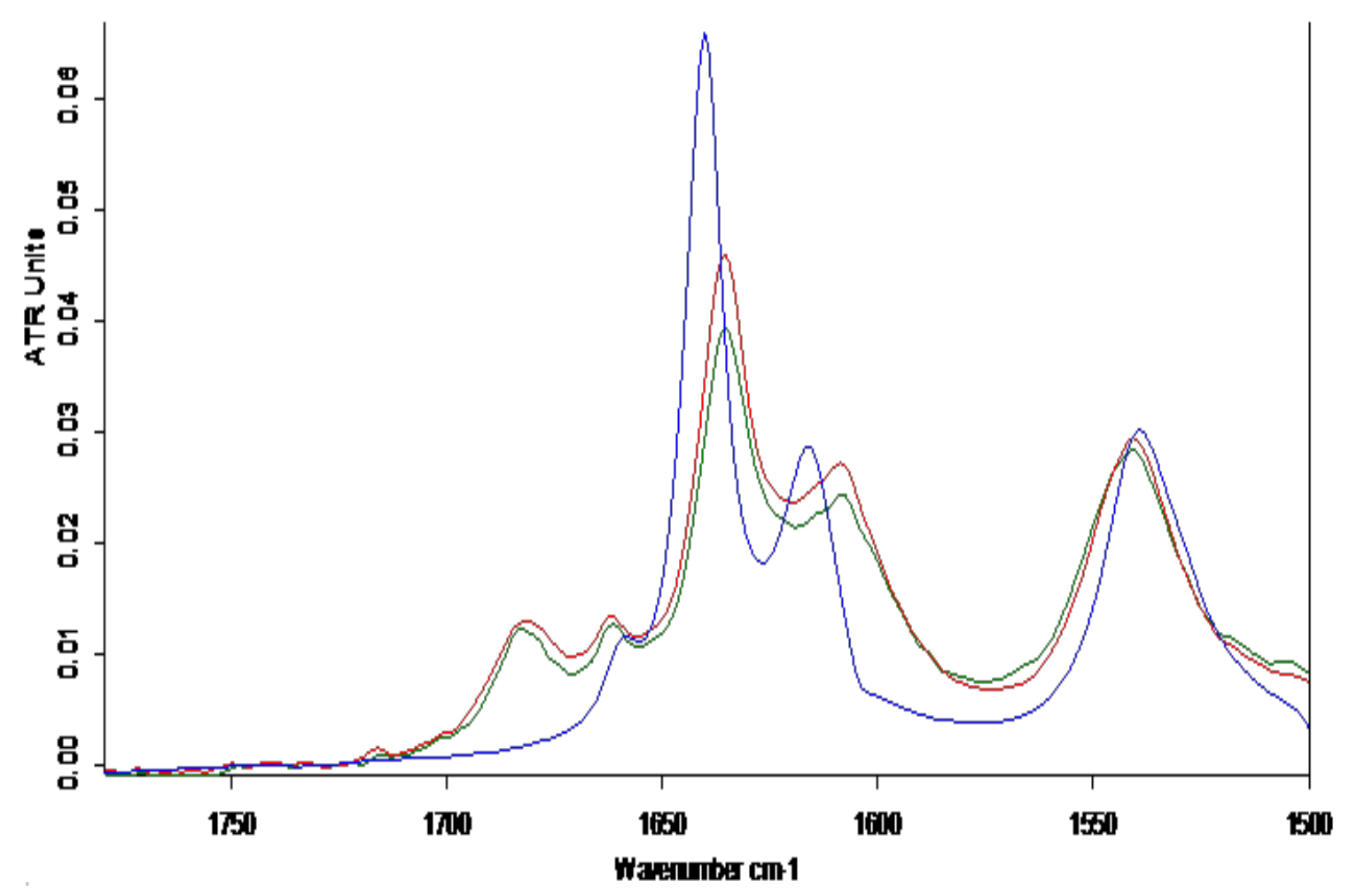

Fig. 3. Amide I region FT-IR spectra of 1 (blue), 2 (red) and 3 (green) in gel state (toluene, $20 \mathrm{mM}$ ). 


\section{Conclusions}

Three new LMWGs based on L-Leucine derivatives 1-3 bearing different alkyl chains (9, 12 , or 16 carbons) at their $\mathrm{N}$-term position and an hydrazide moiety at their C-term position were synthesized. The prepared gelators were fully characterized using ${ }^{1} \mathrm{H},{ }^{13} \mathrm{C}$ NMR, FTIR and mass spectroscopy. LMWGs 1-3 show good gelation behavior in alkanes, aromatics and oils with low CGC. FT-IR study show the primary importance of hydrogen bonding. The morphology of the prepared xerogels was also investigated using SEM.
The modifications introduced on leucine amino acid derivatives lead to efficient organogels with a wide variety of solvents and oils, pointing the way towards many applications.

\section{Acknowledgements}

The authors acknowledge O. Fabre for NMR characterization and Elodie Jeanvoine for FTIR experiments; M.M. Abdellatif thanks Région Lorraine and Lorraine-Université for funding this research.
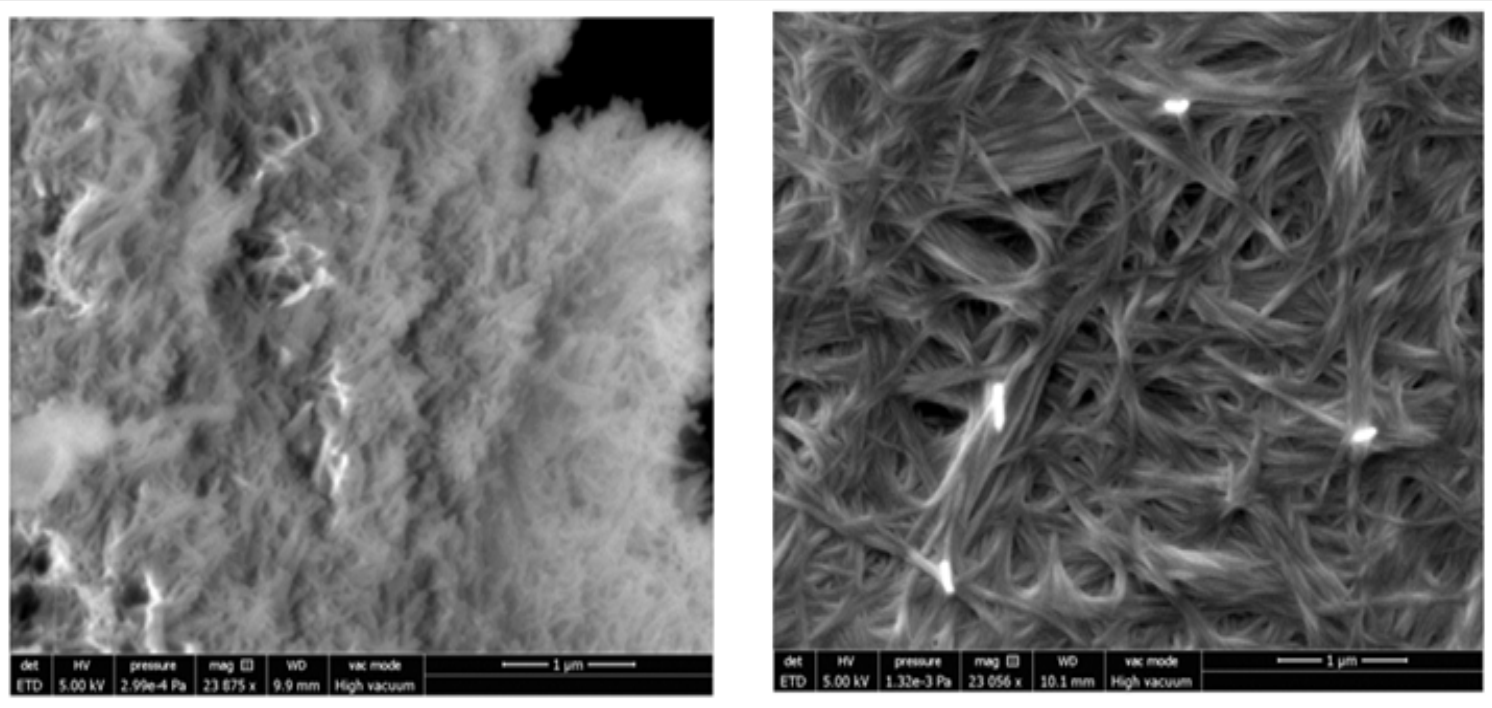

Fig. 4. SEM images of xerogels obtained by open air drying of organogels of $3(1 \mathrm{wt} \%)$ in toluene (left) and in i-Octane (right).

\section{Supporting information}

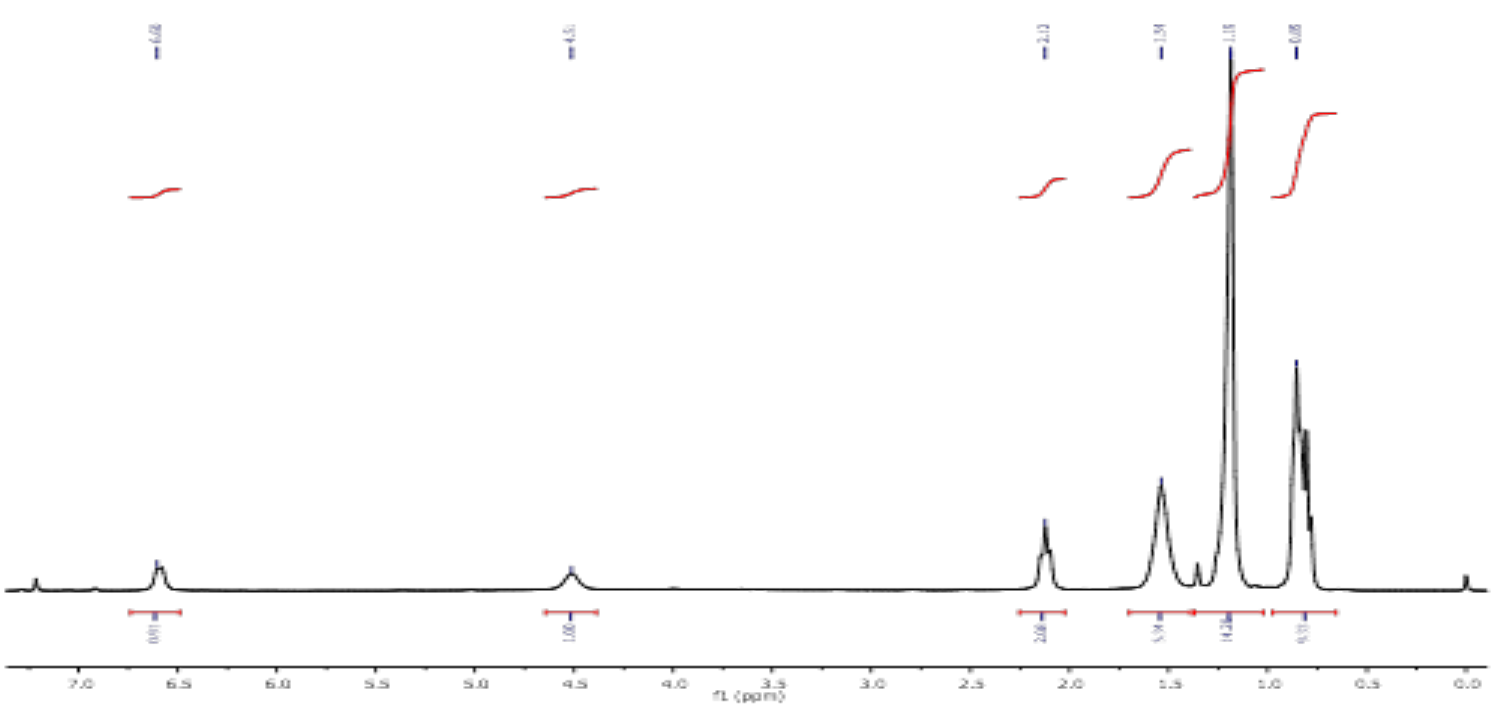

Fig. 1S. ${ }^{1} \mathrm{H}$ NMR chart of 1 (in $\mathrm{CHCl}_{3}$ at $25^{\circ} \mathrm{C}$ ).

J. Text. Color.Polym. Sci. ,15, No. 1 (2018) 


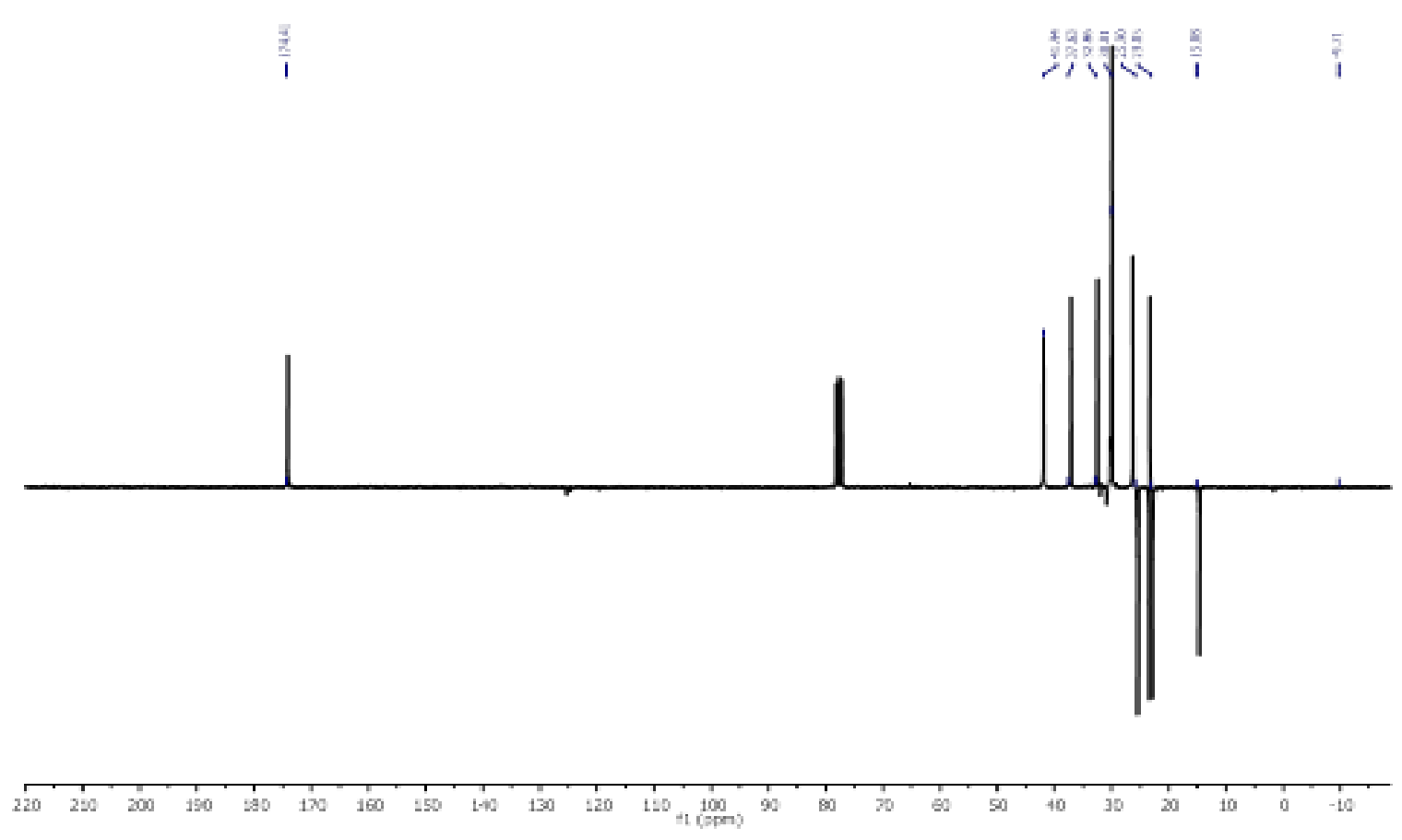

Fig. 2S. ${ }^{13} \mathrm{C}$ NMR chart of 1 (in $\mathrm{CHCl}_{3}$ at $25^{\circ} \mathrm{C}$ ).

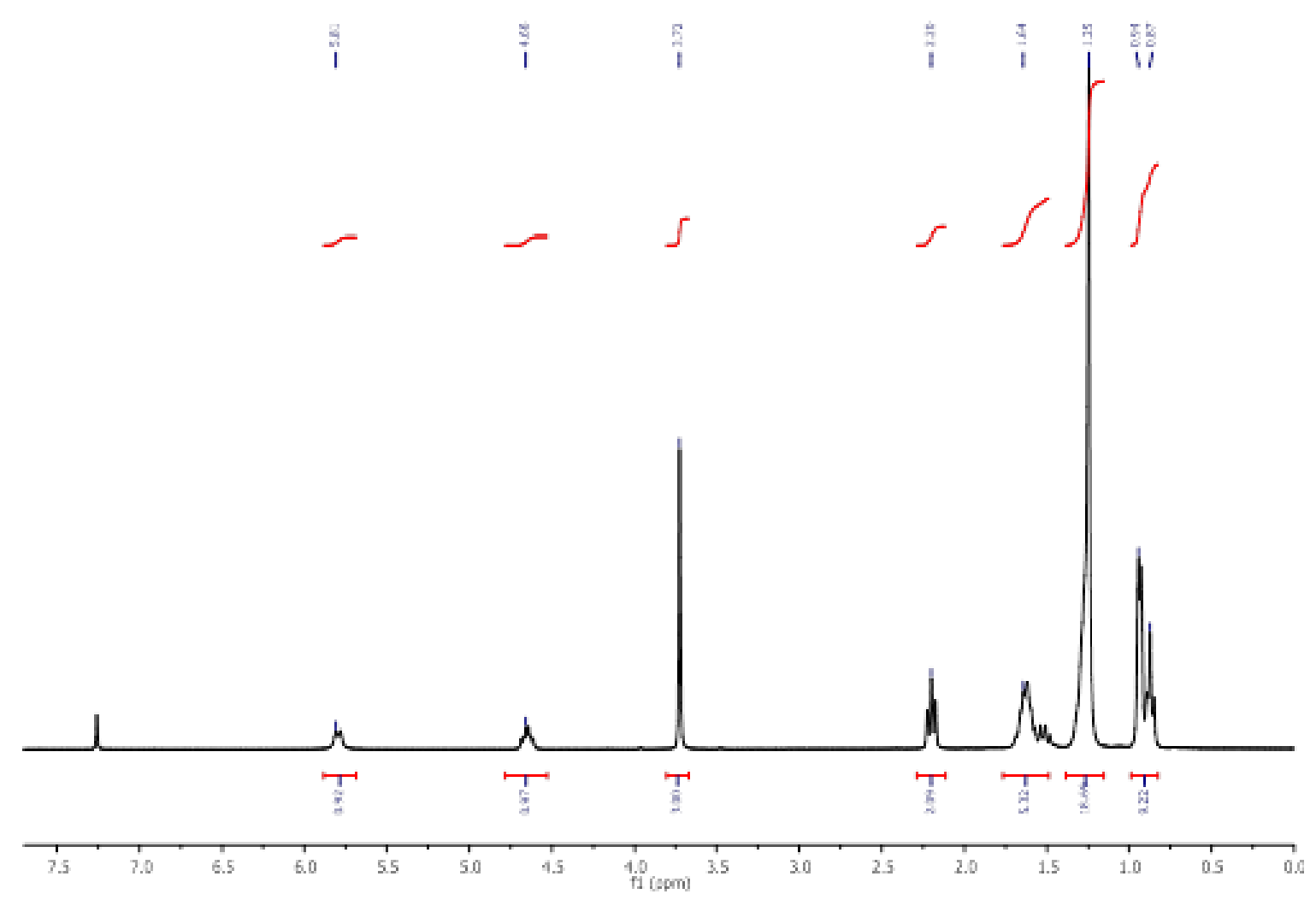

Fig. 3S. ${ }^{1} \mathrm{H}$ NMR chart of $\mathrm{C}_{12}$-Leu-OMe (in $\mathrm{CHCl}_{3}$ at $25^{\circ} \mathrm{C}$ ).

J. Text. Color.Polym. Sci. ,15, No. 1 (2018) 


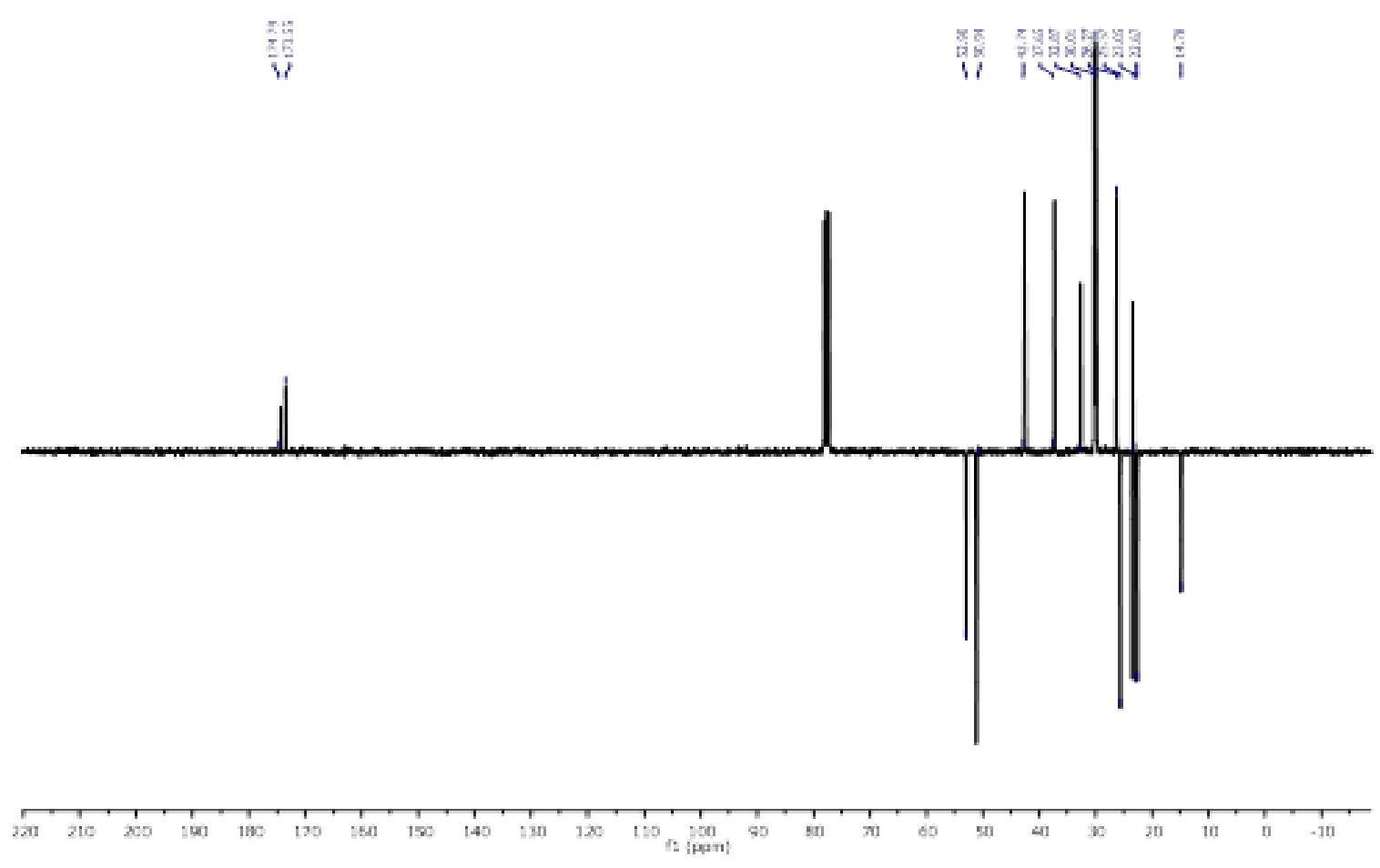

Fig. 4S. ${ }^{13} \mathrm{C}$ NMR chart of $\mathrm{C}_{12}$-Leu-OMe (in $\mathrm{CHCl}_{3}$ at $25^{\circ} \mathrm{C}$ ).

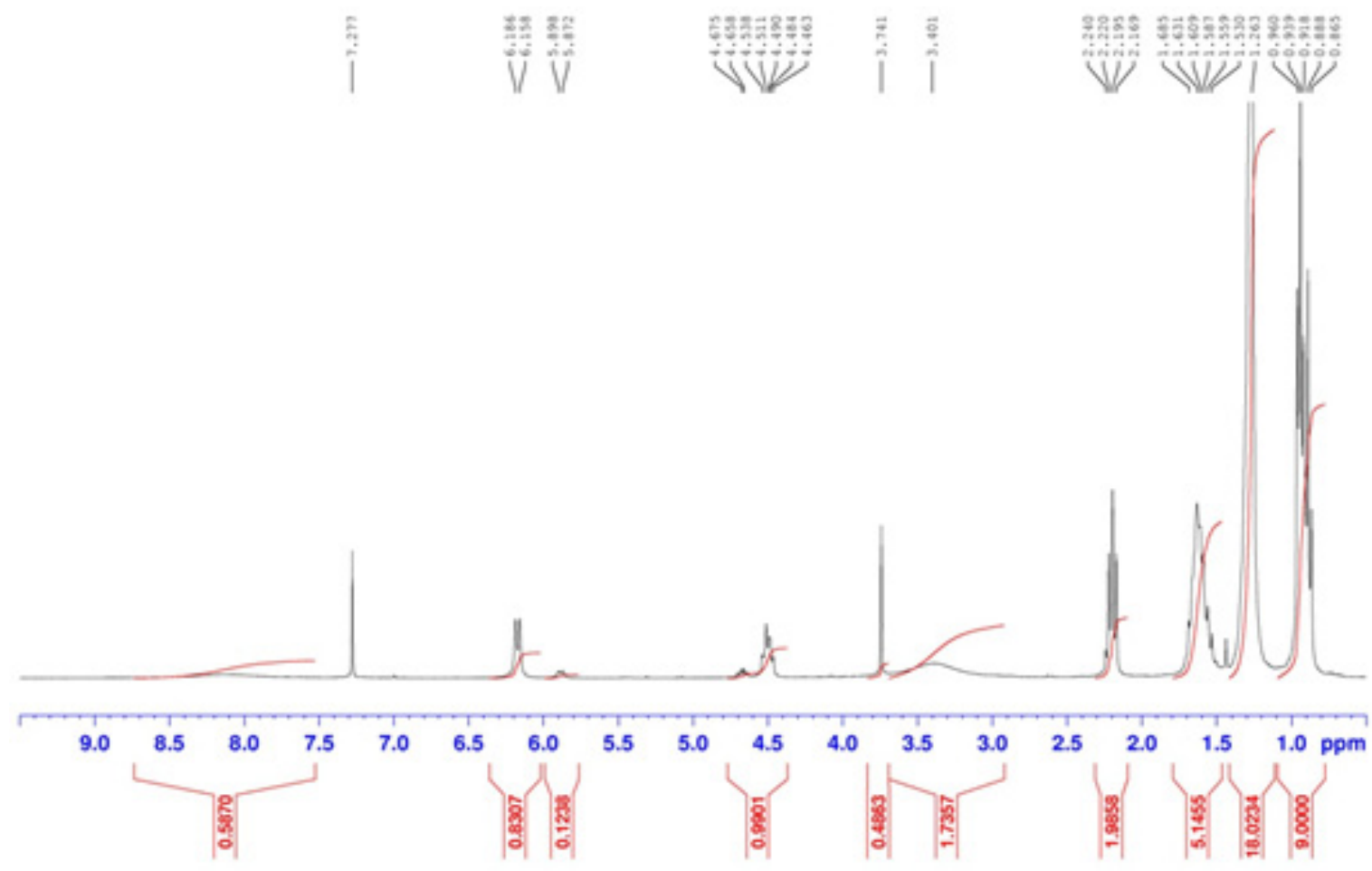

Fig. 5S. ${ }^{1} \mathrm{H}$ NMR chart of 2 (in $\mathrm{CHCl}_{3}$ at $25^{\circ} \mathrm{C}$ ).

J. Text. Color.Polym. Sci. ,15, No. 1 (2018) 


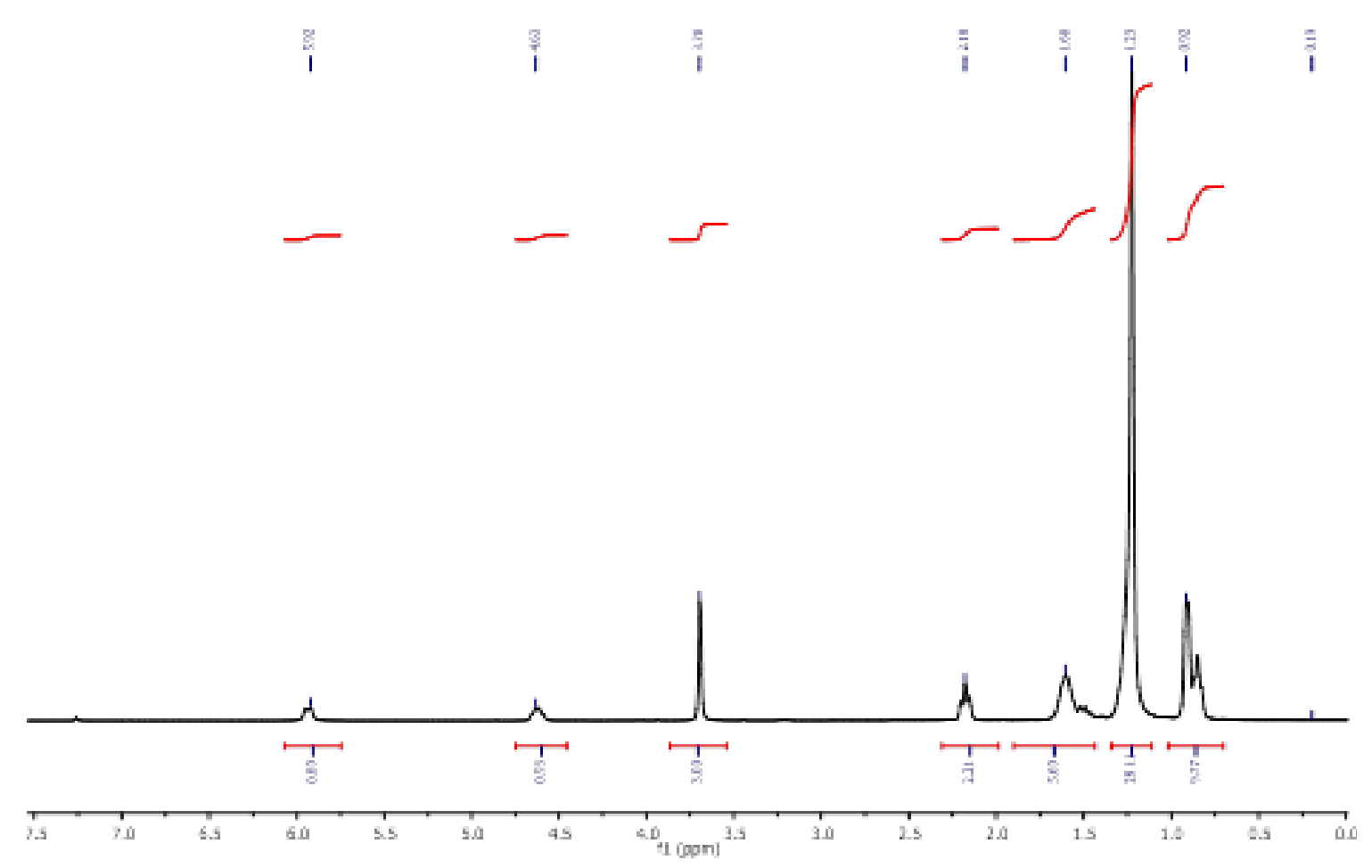

Fig. 6S. ${ }^{1} \mathrm{H}$ NMR chart of $\mathrm{C}_{16}$-Leu-OMe (in $\mathrm{CHCl}_{3}$ at $25^{\circ} \mathrm{C}$ ).

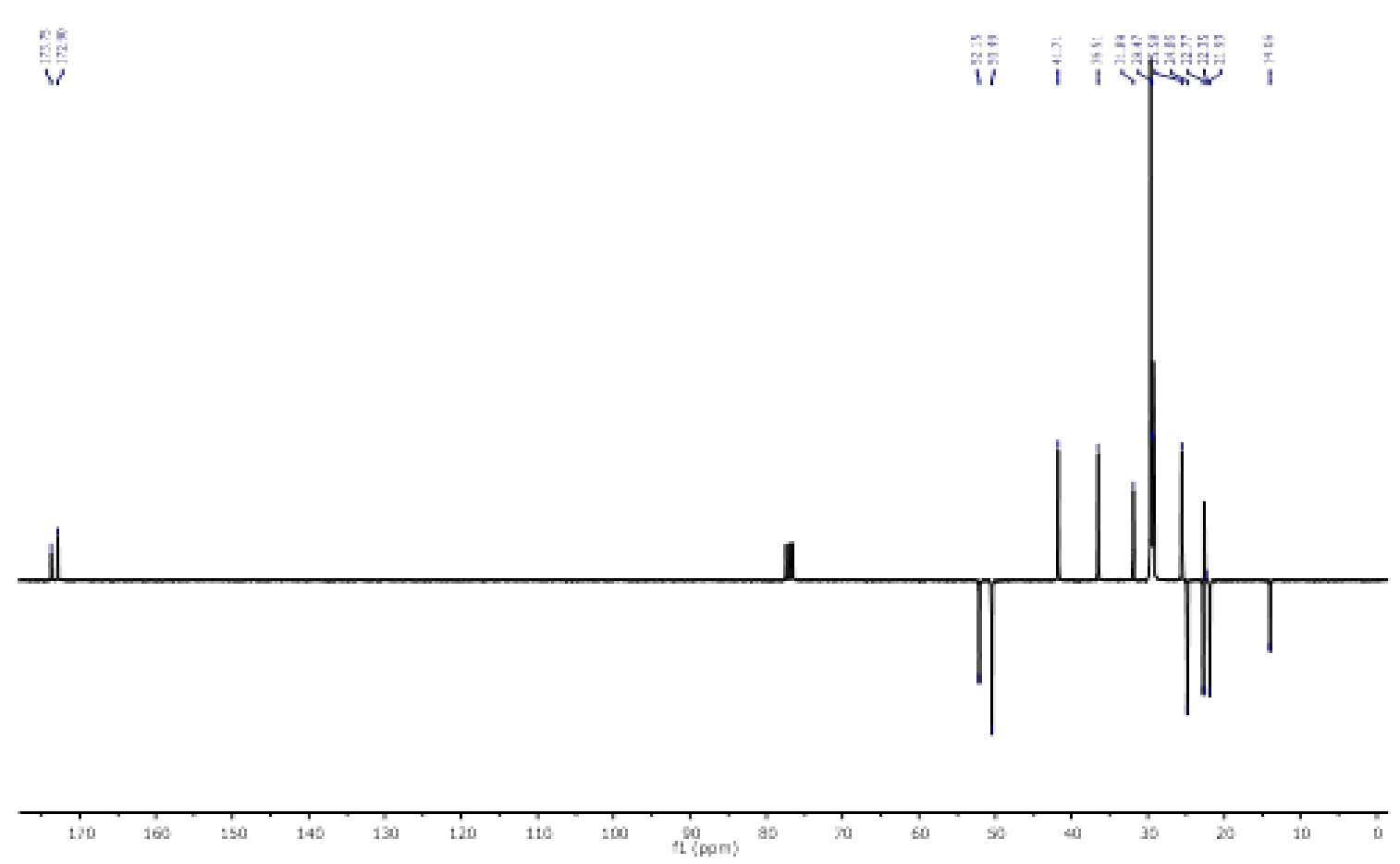

Fig. 7S. ${ }^{13} \mathrm{C}$ NMR chart of $\mathrm{C}_{16}$-Leu-OMe (in $\mathrm{CHCl}_{3}$ at $25^{\circ} \mathrm{C}$ ). 


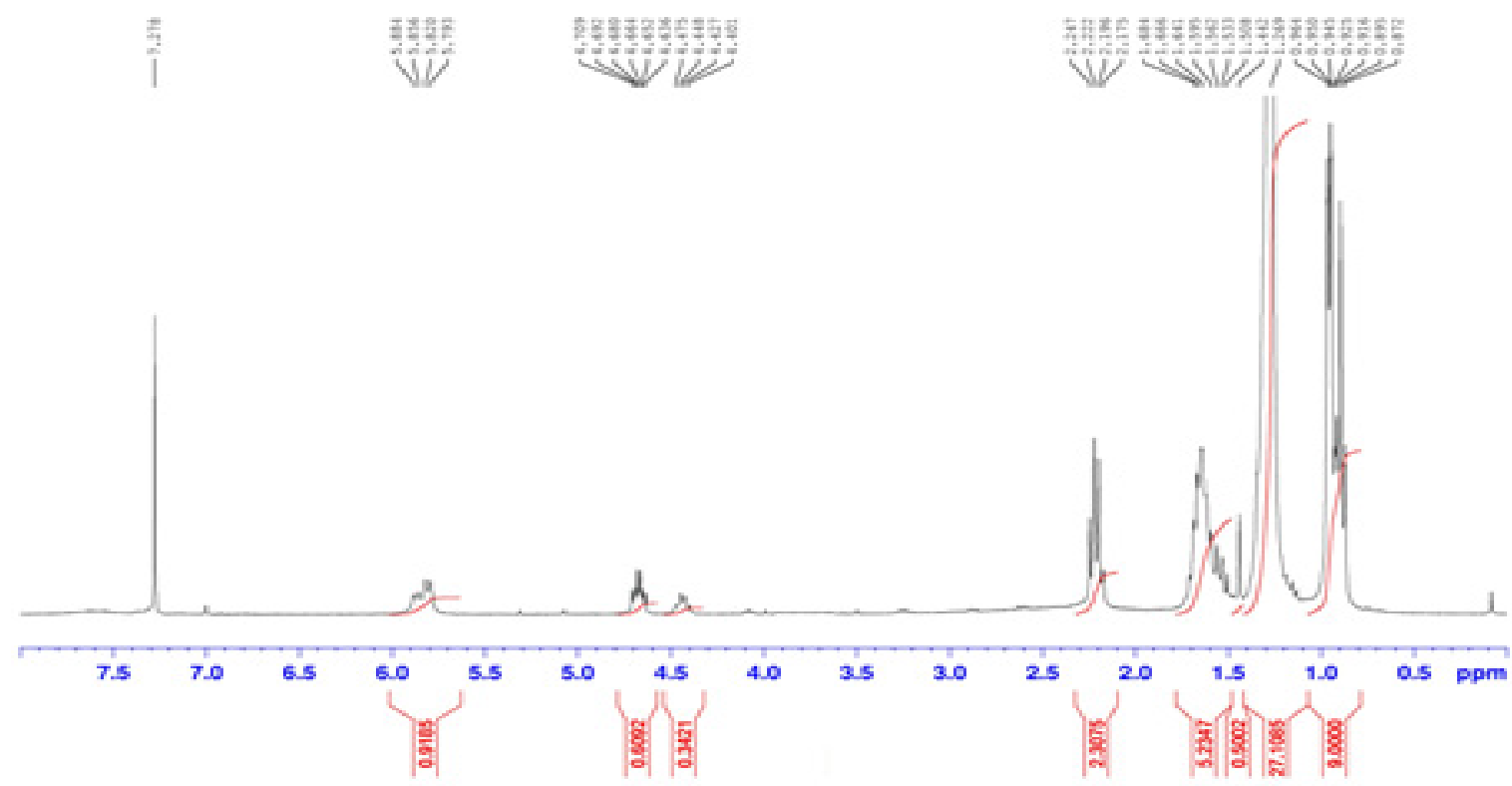

Fig. 8S. ${ }^{1} \mathrm{H}$ NMR chart of ${ }_{3}$ (in $\mathrm{CHCl}_{3}$ at $25^{\circ} \mathrm{C}$ ).

\section{References}

1. N. Falcone, H.-B. Kraatz, Chem A Eur. J., 2018, 24, 14316-14328.

2. S. S. Babu, S. Prasanthkumar, A. Ajayaghosh, Angew. Chem. Int. Ed., 2012, 51, 1766-1776.

3. B. Escuder, F. Rodriguez-Llansola, J. F. Miravet, New J. Chem., 2010, 34, 1044-1054.

4. B. O. Okesola, D. K. Smith, Chem. Soc. Rev., 2016, 45,4226 .

5. C. L. Esposito, P. Kirilov, V. G. Roullin, J. Control Release, 1018, 271, 1-20.

6. J. W. Steed, D. R. Turner and K. Wallace, in Core Concepts in Supramolecular Chemistry and Nanochemistry, Chichester, Wiley, 2007.

7. R. Meléndez, A. Carr, B. Linton and A. Hamilton, Struct. Bonding, 2000, 96, 32-61.

8. F. Delbecq, Adv. Colloid Interface Sci., 2014, 209, 98-108.

9. M. Suzuki, K. Hanabusa, Chem. Soc. Rev., 2009, 38, 967-975.

10. Y. Yu, N. Song, S. Jin, W. Shi, Y. Zhai and C. Wang Acta Chim. Slov. 2013, 60, 644-650.

11. J. Makarevic, M. Jokic, B. Peric, V. Tomisic, B.
Kojic-Prodic and M. Zinic, Chem. A Eur. J., 2001, $7,3328-3337$.

12. J. Boekhoven, A. M. Brizard, M. C. A. Stuart, L. Florusse, G. Raffy, A. Del Guerzo and J. H. van Esch Chem. Sci.,2016,7,6021- 6031.

13..S. R. Raghavan, B. H. Cipriano, in Molecular Gels: Materials with Self-Assembled Fibrillar Network, Springer, 2005, 233-244

14.. W. Edwards, C. A. Lagadec and D. K. Smith, Soft Matter, 2011, 7, 110-117.

(Received $30 / 10 / 2018$

accepted $9 / 12 / 2018$ )

J. Text. Color.Polym. Sci. ,15, No. 1 (2018) 


\section{أستخدام مشتقات الليوسين ذات مجموعة الهيدرازيد الطرفية كمواد مجلتنة للعديد من

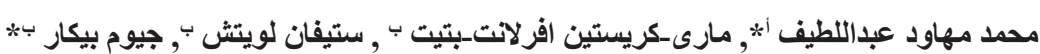

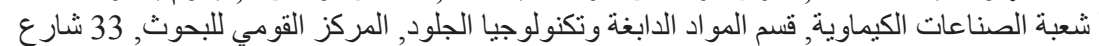

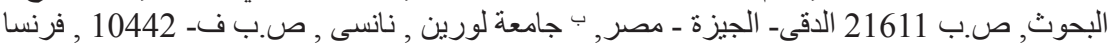

\footnotetext{
ثلاثة مواد مجلتنة صغيرة الوزن الجزيئي تم تحضيرهم وتصميمهم بأستخدام الليوسين ذات مجموعة

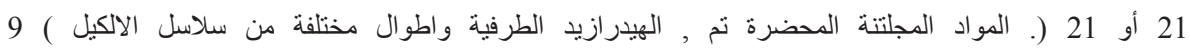

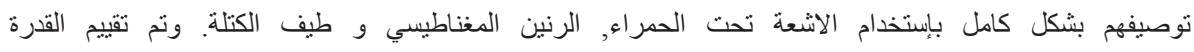
الجيلاتينية للمركبات المحضرة باستخدام مذيبات عضوية وزيوت مع تعيين التركيز الحرج لتكوين لتكوين الجيلاتين.

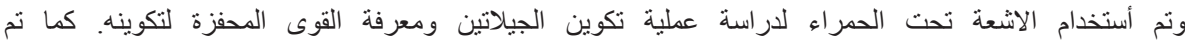
استخدام الميكروسكوب الالكترونى لدر اسة الخو اص السطحية للجيل الهو ائي.
} 